\title{
PRZEPŁYW DANYCH \\ W PLACÓWCE INFORMACYJNEJ CALL CENTER ${ }^{1}$
}

\author{
Jan Dionizy Mejor \\ Biblioteka Narodowa
}

Systemy informacyjne, call center, przepływ informacji, przepływ danych, telekomunikacja, analiza systemowa, analiza strukturalna, projektowanie systemów informacyjnych, diagramy przepływu danych

Jednym z systemów informacyjnych spoza tradycyjnej biblioteki są coraz częściej spotykane call centra lub raczej contact centra. Sa to nowoczesne placówki informacyjne, przechowujące dane i udzielające informacji związanych z prowadzona przez firmę działalnością. Contact center są placówkami ściśle powiązanymi z działalnościa wielkich korporacji, ich systemy i sposoby działania są objęte tajemnicą handlową tychże firm.

Część pierwsza artykułu ma przybliżyć i usystematyzować pojęcia zwiazane z placówką informacyjną call center, część druga poświęcona jest zagadnieniu przepływu danych i ich diagramom. Wiadomości teoretyczne oparte są na podręczniku analityka Edwarda Yourdona. W części trzeciej dokonany został przegląd istniejących wdrożeń systemów dla centrum telefonicznej obsługi klientów. Przykłady zostały wybrane losowo, tak aby ukazać części wspólne dla wszystkich systemów tego typu. Na ich podstawie został zbudowany pełny, wielopoziomowy diagram przepływu danych placówki informacyjnej call center.

\section{Call center - podstawowe informacje i najważniejsze elementy}

Call Center, Biuro Obsługi Klienta, Infolinia i Contact Center. Oto kilka przykładowych pojęć, które potocznie używane są wymiennie. Nie oznacza to jednak, że sa jednoznaczne. Pojęciem najwęższym jest infolinia. Jest to „numer telefoniczny (czasem internetowy), pod którym można zgłosić pytanie na temat używanych produktów, zwłaszcza oprogramowania"2. Infolinie to wszystkie numery typu 0-800, przez które kontaktujemy się z firmą. Zbliżoną definicję podaje w swoim glosariuszu Marian Kostecki: infolinia to „linia informacyjna. Numer telefonu, pod którym można się dowiedzieć o firmie, produkcie, usłu-

${ }^{1}$ Artykuł na podstawie pracy magisterskiej pt. Diagram przepływu danych placówki informacyjnej Call Center złożonej na kierunku Informacji Naukowej i Studiów Bibliologicznych Uniwersytetu Warszawskiego w 2011 r. Promotor: prof. dr hab. Mieczysław Muraszkiewicz.

${ }^{2}$ WIKIPEDIA [online]. [dostęp: 22.10.2012]. Dostępny w World Wide Web: <http://pl.wikipedia.org/wiki/lnfolinia>. 
dze. Często kojarzona z linią bezpłatną lub częściowo płatną"3. Infolinie zatem automatycznie łączą klienta z odpowiednim działem, firma, serwisem kontaktowym. Wszyscy klienci danej firmy korzystaja z jednego numeru, a kolejne połączenia rozdzielane sa między pracowników obsługi na zasadzie losowej, bądź według zadanego schematu (w mowie potocznej często zamiast infolinii używa się zwrotu informacja, np. informacja PKP lub PKS).

Czym jest ta instytucja, oddział firmy, placówka kryjąca się za numerem infolinii? Jednym rodzajem takich placówek może być Call Center, czyli „organizacja lub jednostka organizacyjna, w której każdy kontakt z klientem (połączenie, zgłoszenie) może być obsługiwany przez jedną lub wiele osób, mających dostęp do wspólnej informacji”“4 (należy zaznaczyć, że chodzi tu o kontakt telefoniczny). Definicja podana przez Kosteckiego znajduje potwierdzenie w tłumaczeniu terminu na język polski: call - dzwonić, center - centrum, ośrodek ${ }^{5}$, czyli centrum dzwonienia, a bardziej fachowo, Centrum obsługi telefonicznej. Tłumaczenie, zaproponowane przez Aleksandra Lotko, wydaje się odzwierciedlać istotę placówki call center. Zwraca on uwagę na funkcję pełniona przez tę placówkę, czyli na obsługę klienta. „Pojedynczy punkt kontaktu (jednostkę organizacyjna), którego zadaniem jest obsługa zgłoszeń, zapytań, problemów i innych kwestii związanych z obsługa klienta. Dział ten to centrum kontaktu z klientem, nazywany potocznie call center" 6 . Call center jest zatem placówka, instytucja zajmująca się rozpatrywaniem próśb, zażaleń i, ogólnie, kontaktem z klientami firmy za pośrednictwem telefonu. W dalszej części poradnika Aleksander Lotko napisał: „Nazwa call center podkreśla rolę i sposób funkcjonowania działu, którego zadanie polega na profesjonalnej obsłudze dużych ilości zgłoszeń, głównie z wykorzystaniem kontaktu telefonicznego, a także działalność telemarketingowa." Call centra rolę informacyjną mogą pełnić nie tylko czekając na zgłoszenie klienta, ale moga być aktywne i same podejmować działania informacyjne, dzwoniąc do klientów. Taka definicja call center przyjęta jest również przez Kosteckiego ${ }^{8}$. Wymienia on kilka odmian tego typu placówek, między innymi call centra wirtualne, czy „na żądanie”. Dzięki zastosowaniu nowoczesnych centrali PABX możliwe jest tworzenie call center bez fizycznej siedziby. Numer infolinii poprzez centralę może przekierowywać połączenia do agentów pracujących w domu lub terenie. Innym rodzajem sa call centra outsourcingowe, czyli duże placówki wynajmujące swoje stanowiska mniejszym firmom.

Pierwsze ośrodki tego typu powstały już w latach 70 . ubiegłego wieku. Dziś jest to jeden z najpopularniejszych sposobów kontaktu z klientem, ale nie tylko. Powstaja rozmaite programy umożliwiające obywatelom uzyskanie pomocy: Rodzinny Telefon Zaufania lub Pomocna Zielona linia dla osób szukających

${ }^{3}$ M. J. Kostecki: Glosariusz terminologii call center/help desk. Warszawa 2007, s. 115.

${ }^{4}$ Ibidem, s. 59.

${ }^{5}$ Oxford wordpower: słownik angielsko-polski i polsko-angielski. Oxford 2007.

${ }^{6}$ A. Lotko: Efektywne inwestowanie w centrum kontaktu z klientem. Radom 2005, s. 40.

7 Ibidem.

${ }^{8}$ Call center - „Jednostka organizacyjna prowadząca intensywne kontakty telefoniczne z klientami i potencjalnymi klientami. Niekiedy używane jest określenie TELECENTRUM”. M. J. Kostecki: Glosariusz..., op. cit., s. 59. 
pracy. Coraz popularniejsze są call centra typu dyzurnet. $\mathrm{pl}^{9}$, gdzie można zgłaszać szkodliwe strony internetowe. Od lat istnieją również telefony alarmowe 998, 997, 112. Są to infolinie obsługiwane przez grupę przeszkolonych osób, posługujących się centralną bazą danych. To też są Call Centra.

Nowoczesna technologia oraz centrale PABX umożliwiaja nie tylko wykonywanie połączeń głosowych, ale również przesyłanie faxów, sms'ów, zdjęć, maili czy materiałów wideo, nie są to jednak call center, ale contact center.

Jak napisał Aleksander Lotko: „Tradycyjnego pojęcia „call center” używa się dziś nieco rzadziej. Wynika to z faktu znacznej ewolucji, przede wszystkim technicznej, jaką przeszły te rozwiązania od początku lat siedemdziesiątych. Ogromny wzrost możliwości telekomunikacyjnych, a więc zróżnicowanie kanałów kontaktu z klientem spowodowało upowszechnienie się nazwy contact center, jako abstrahującej od rodzaju używanego sposobu kontaktu"10. Doskonałym przykładem są firmy telekomunikacyjne. Podstawowym ich produktem jest telefon, usługa telekomunikacyjna. Kontakt z klientem nie jest jednak ograniczony tylko do telefonu. W przypadku Telekomunikacji Polskiej może to być kontakt drogą internetowa, e-mailowa, faxem lub pocztą ${ }^{11}$. Ponadto informacje reklamowe lub promocyjne docierają do nas za pomocą radia i telewizji. Są również sytuacje w których tradycyjny kontakt telefoniczny nie wystarczy. W większości firm, w tym TP S. A., zerwanie umowy może się odbyć jedynie droga pisemną ${ }^{12}$.

Ewolucję, jaka zaszła w call centrach, podkreśla również Kostecki. Terminu contact center używa on dla podkreślenia, że dana placówka wykorzystuje nie tyko telefon, ale i inne metody kontaktu z klientem. "Contact center to termin, którego używa się dla podkreślenia, że konkretne call center w sposób uporządkowany (zintegrowany) obsługuje kontakty telefoniczne, faksowe i e-mailowe, zgłoszenia umieszczane na witrynach WWW, chat (pogawędki internetowe), SMS-y i pocztę głosowa" ${ }^{13}$. Biuro Obsługi Klienta, Contact Center lub Centrum Kontaktu z Klientem to zatem „całość infrastruktury służącej przedsiębiorcom do masowego kontaktu z klientami przy użyciu jednego bądź wielu środków komunikacji, zwłaszcza indywidualnych"14. Jest to pojęcie szersze od call center. Nie ma sprecyzowanego środka kontaktu. Może to być telefon, ale nie jest to jedyny sposób porozumiewnia się z klientem. Dokładnie taką definicję Centrum Kontaktu podaje w swojej książce Aleksander Lotko. „Poszukując zwięzłej i trafnej definicji pojęcia można powiedzieć, że centrum kontaktu z klientem to zespół ludzi, urządzeń i technologii umożliwiające kontakt pomiędzy dostawcą

${ }^{9}$ Dyżur.net. [online]. [dostęp: 22.10.2012]. Dostępny w World Wide Web: <http://www. dyzurnet.pl>.

${ }^{10}$ A. Lotko: Efektywne inwestowanie w centrum kontaktu z klientem. Radom 2005, s. 42.

${ }^{11}$ Obsługa Klienta. [online]. [dostęp: 22.10.2012]. Dostępny w World Wide Web: <http:// www.tp.pl/prt/pl/klienci_ind/obsluga_klienta/kontakt/>.

$12, \S 9$ 1. Umowa o korzystanie $\bar{z}$ abonamentu radiotelefonicznego może być rozwiązana przez: 1/ abonenta z zachowaniem miesięcznego okresu wypowiedzenia, ze skutkiem na koniec miesiąca, przez pisemne oświadczenie złożone w TP S.A.-CRT" - fragment regulaminu o świadczeniu usług przez TP. S. A.

${ }^{13}$ M. J. Kostecki: Glosariusz...., op. cit., s. 60.

${ }^{14}$ WIKIPEDIA. [online]. [dostęp:22.10.2012]. Dostępnyw WorldWideWeb: <http://pl. wikipedia.org/wiki/Biuro_obs\%C5\%82ugi_klienta>. 
a klientem wszelkimi możliwymi środkami komunikacji” ${ }^{15}$. W dobie „społeczeństwa Informacyjnego" sposobów dotarcia do klienta jest bardzo wiele. Im więcej sposobów, środków kontaktu wykorzystuje firma, tym większa szansa na skuteczne dotarcie do klienta.

\section{Diagram przepływu danych}

Diagram przepływu danych jest to graficzny obraz wybranego systemu. Jednocześnie jest to jedno $z$ narzędzi służących do modelowania, tworzenia systemu. „Diagram przepływu danych jest narzędziem modelowania pozwalającym zobrazować system jako sieć procesów funkcyjnych, połączonych ze soba ,potokami” i „zbiornikami” danych. Diagram przepływu to jedno z najczęściej używanych narzędzi modelowania systemów, zwłaszcza dla systemów operacyjnych, w których funkcje systemu są ważniejsze i bardziej złożone niż dane, którymi manipuluje system"16. Korzystając z diagramu przepływu danych, w skrócie DPD lub DFD ${ }^{17}$ (ang.), można zbudować graficzny obraz systemu, z naciskiem na jego funkcje na poszczególnych etapach. Dzięki takim diagramom można stworzyć model całego systemu zarządzania danymi w przedsiębiorstwie, z uwzględnieniem najważniejszych jego funkcji, czyli planowania, organizowania, przewodzenia i (w wersji rozszerzonej DFD) kontrolowania. Diagramu przepływu danych nie należy mylić z algorytmami, które są ciagami zadań do wykonania dla systemu.

DFD nie istniałyby bez swojego charakterystycznego zapisu. Standardy notacji i jej podstawy sięgają lat 70 -tych. Wtedy powstały takie prace jak Analiza strukturalna i specyfikacje systemów DeMarco ${ }^{18}$ czy Strukturalna analiza systemowa: narzędzia i techniki Gane i Sarson ${ }^{19}$. Do dziś, tworząc modele DFD, posługujemy się notacją i zasadami na nich opartymi.

Każdy diagram ma zatem ustaloną strukturę. Tworząc je, analityk ma do dyspozycji pewien standardowy zbiór elementów. Ponadto każdy diagram ma ścisłe zasady łączenia tych elementów, ma swoją gramatykę. Można mówić więc o języku diagramów. Podstawowymi elementami każdego diagramu są:

- Proces,

- Terminator,

- Magazyn,

- Przepływ.

Do poszczególnych elementów przyporządkowane sa graficzne oznaczenie oraz zbiór reguł dotyczących jego oznaczenia, nazewnictwa i funkcji w systemie. Dzięki zastosowaniu notacji, czy też, jak to określiłem wcześniej, języka, dobrze wykonany diagram będzie czytelny dla użytkownika.

${ }^{15}$ A. Lotko: Efektywne..., op. cit., s. 41.

${ }^{16}$ E. Yourdon: Współczesna analiza strukturalna. Warszawa 1996, s. 126.

${ }^{17}$ DFD - Data Floath Diagram (ang.) - Diagram Przepływu Danych.

18 T. DeMarco: Structured analysis and system specification. Englewood, New Jersey, 1979.

${ }^{19}$ Ch. Gane, T. Sarson: Structured systems analysis: Tools and techniques. Englewood, New Jersey, 1979. 
W podręcznikach i artykułach dotyczących DFD jako pierwszy element wymienia się Proces, pozwoliłem sobie jednak jako pierwszy element składni diagramów zaprezentować Przepływ, ponieważ mówimy o diagramie przepływów, a nie procesów czy terminatorów.

Przepływ reprezentowany jest przez strzałki biegnące pomiędzy prostokątami i okręgami. Część z nich jest podpisana. Jest to informacja o tym co dany przepływ przenosi pomiędzy poszczególnymi elementami diagramu. Przepływ jest to „... proces przenoszenia pakietów informacji pomiędzy elementami systemu lub pomiędzy obiektami zewnętrznymi oraz systemem"20. Niemal identyczną definicje przepływu podaje Edward Yourdon: „Przepływ reprezentuje się graficznie strzałką do lub z procesu. Służy on do opisania przenoszenia jednostek lub pakietów informacji z jednego fragmentu systemu do innego".

Co ciekawe, z zagadnieniem przepływu informacji można się zetknąć nie tylko w opracowaniach dotyczących DFD, popularnym pojęciem są one chociażby w logistyce. Przytoczę fragment kompendium pod redakcją E. Gołembskiej: „Wszelkim przepływom materialnym towarzysza przepływy informacji. Wymiana informacji między nadawca a odbiorca jest warunkiem przepływu dóbr między punktem nadania a punktem odbioru. Zaczyna się ona jeszcze przed poczęciem przepływu materialnego. Dotyczy na przykład przesłania oferty handlowej do potencjalnego klienta i jego odpowiedzi w postaci wysłania zamówienia na określone towary"21.

Magazyn danych to miejsce, gdzie przechowywane sa dane istotne dla firmy. Magazyn służy do buforowania danych wykorzystywanych przez kilka procesów. W odróżnieniu od przepływu magazyn przedstawia dane w spoczynku, a nie w ruchu ${ }^{22}$. „Magazyn służy do modelowania zbioru danych w bezruchu. Oznacza się go dwoma równoległymi liniami. Zwykle nazwa wybrana dla magazynu to liczba mnoga od nazwy pakietów przenoszonych przepływami do i z magazynu"23. Na rysunku 1 przedstawiono przykłady dwóch magazynów. Jest to jedna z form zapisu tego elementu DFD (najprostsza to prostokat). W systemie rzeczywistym, który reprezentuje diagram, magazyn może być zarówno komputerową bazą danych, jak i segregatorem z danymi w postaci papierowej. Nie ma to znaczenia dla DFD ${ }^{24}$.

${ }^{20}$ J. Jakieła: Materiały do laboratoriów z przedmiotu Informatyczne Systemy Zarządzania. [online]. Dostępny w World Wide Web: <http://jjakiela.prz.rzeszow.pl/dfd.htm>.

${ }^{21}$ Kompendium Wiedzy o Logistyce. Red. E. Gołembska. Warszawa 2001, s.157.

22 „Przepływ przedstawia dane w ruchu podczas gdy magazyn danych przedstawia dane w spoczynku. Nazwa pakietu reprezentuje znaczenie pakietu poruszającego się wzdłuż przepływu. Należy pamiętać, że w modelu fizycznym systemu, tzn. modelu, który przedstawia stan obecny organizacji dla której chcemy zaprojektować system na przepływach oprócz pakietów informacji moga pojawić się również obiekty fizyczne”. E. Yourdon: Współczesna analiza..., op. cit., s. 135.

${ }^{23}$ E. Yourdon: Współczesna analiza..., op. cit., s. 135.

24 „Analitycy o wykształceniu informatycznym mają tendencję nazywania magazynów plikami lub bazami danych (np. plikami na taśmie magnetycznej, plikami dyskowymi pod nadzorem IMS, DB2, ADABAS, IDMS lub innego znanego systemu zarzadzania baza danych). Magazyny rzeczywiście implementuje się w ten sposób w systemach skomputeryzowanych; ale mogą być nimi także dane przechowywane na kartach perforowanych, mikrofilmach, mikrofiszkach, dysku optycznym lub w wielu innych postaciach elektronicznych. Magazyn może też składać się z kart indeksowych 3/5 w tekturowym pudełku, nazwisk i adresów w książce adresowej, kilku segregatorów na półce lub z innych nieskomputeryzowanych form". Ibidem, s. 136. 
Proces to kolejny element systemów przepływu danych. Bardzo często jest przedstawiany jako pierwszy, co spowodowane jest jego rola w systemie. To tu dokonuja się bowiem przekształcenia i transformacje danych. To proces może zadecydować o odczycie i zapisie danych w magazynie, jednak bez danych (pobranych z magazynu bądź dostarczonych przez przepływ) proces nie będzie działał. „Pierwszy składnik DFD nazywa się procesem. Popularne synonimy to bąbel, funkcja lub transformacja. Proces pokazuje pewien fragment systemu przekształcający dane na wyniki, tzn. sposób w jaki pewne dane zamieniaja się w pewne wyniki. Graficznie proces reprezentuje się okręgiem"25.

Proces symbolizuje więc element systemu, w którym przetwarzane są dane. Wprowadzając dane do Procesu, uruchamiamy go i otrzymujemy wynik w postaci przetworzonych danych. Dobrym przykładem jest prosty proces zaprezentowany na stronie internetowej dr. inż. Jacka Jakiełły ${ }^{26}$, nazwany Przyjmij zamówienie. Proces ten jest odpowiedzialny za pobranie informacji o kontrahencie i zamawianym produkcie. Zapisuje on informacje $w$ dwóch magazynach danych Klienci oraz Zamówienia i jednocześnie przesyła informacje do procesu odpowiedzialnego za realizację zamówienia (na diagramie proces jest kwadratem o zaokraglonych rogach $)^{27}$. Proces ma przypisany numer, w tym wypadku P1, oraz krótką nazwę Przyjmij zamówienie.

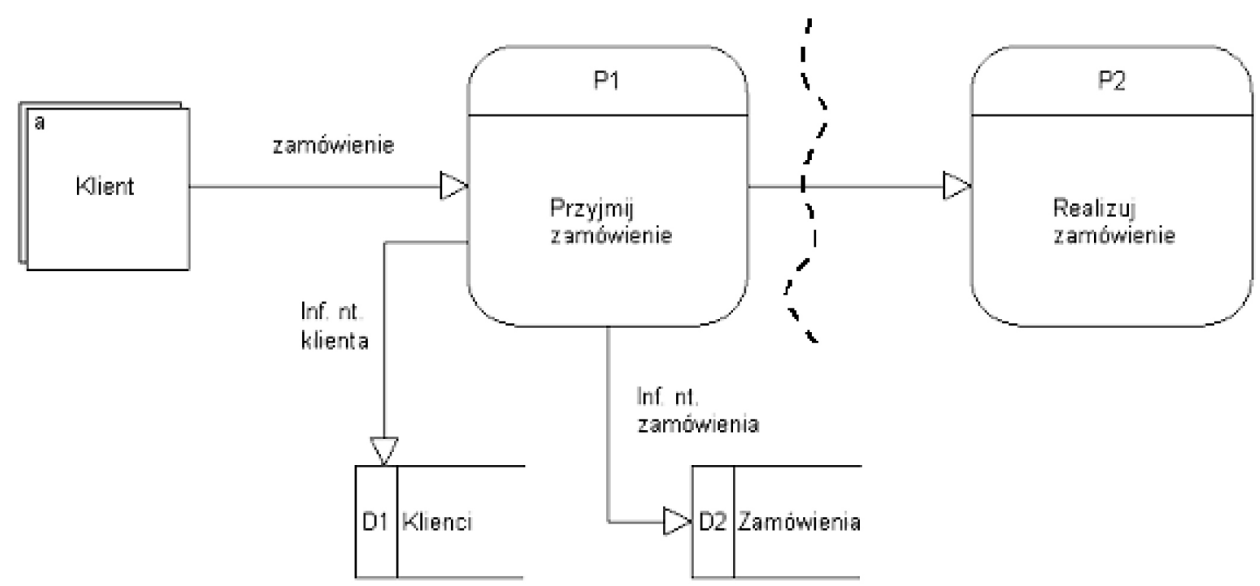

Rys. 1. Przykład prostego procesu przetwarzającego dane.

Rysunek pochodzi ze strony internetowej: http://jjakiela.prz.rzeszow.pl/dfd.htm

${ }^{25}$ Ibidem, s. 129.

26 J. Jakieła: Materiały..., op. cit.

${ }^{27}$ „Kształt używany przez analityka dla procesu jest często związany z „obozem” analizy strukturalnej. Okrag jest związany z obozem „Yourdon/DeMarco”, ponieważ jest używany w wielu książkach publikowanych przez YOURDON Press, jak też podczas szkoleń i konsultacji firmy YOURDON Inc. Elipsa jest często stosowana przez obóz „Gane/Sarson”, ponieważ została wprowadzona przez Chrisa Gane i Trish Sarson w ich książce [Gane i Sarson, 1977] i jest używana przez McDonnell Douglas Automation Company (McAu-to) oraz inne organizacje. Prostokąt jest zwykle związany z obozem „SADT”, ponieważ został spopularyzowany w różnych artykułach o Softech's Structured Analysis Design Technique (SADT); zob. np. [Ross i Schoman, 1977]. E. Yourdon: Współczesna analiza..., op. cit., s. 129. 
Ostatnim elementem DFD są tzw. Terminatory. Symbolizują one zewnętrzne obiekty spoza systemu, na przykład osobę lub firmę, z którą system się komunikuje. W opisywanym przykładzie na rys. 1 . terminatorem jest Klient. Yourdon podaje następującą definicję terminatora DTD: „[...] terminator; graficznie przedstawia się go za pomoca prostokąta. Terminatory reprezentuja zewnętrzne obiekty, z którymi komunikuje się system. Zwykle jest to osoba lub grupa osób, np. zewnętrzna firma lub agenda administracyjna, grupa lub dział w tej samej firmie co modelowany system, ale poza jego kontrola. Czasem terminator może być innym systemem, np. informatycznym, z którym komunikuje się twój system"28.

Terminatorem może być praktycznie każdy zewnętrzny element, z którym nasz system będzie się komunikował. Czytając diagram przepływu danych, można mieć wrażenie, że terminator jest początkiem całego systemu, ale ten sam terminator może występować w kilku miejscach na diagramie, nie jest bowiem tak, że tylko jeden proces może się z danym terminatorem komunikować.

\section{Gramatyka diagramu}

Poprzednio zaprezentowałem elementy składowe każdego diagramu przepływu danych - jest to alfabet DFD. Aby móc skonstruować poprawny diagram, potrzebne sa jeszcze reguły łączenia poszczególnych elementów - gramatyka DFD. Podstawowe zasady tworzenia dobrych DFD, to:

1. Terminatory nie komunikują się ze soba, bo obiekty zewnętrzne nie moga się ze sobą komunikować w systemie (to tak, jakby kazać klientowi składajacemu zamówienie w księgarni kazać udać się do banku i tam zostawić swoje dane do faktury) ${ }^{29}$. Komunikacja $z$ terminatorami (obiektami zewnętrznymi) może zachodzić tylko za pośrednictwem systemu (księgarnia pobiera dane od klienta i przesyła - te wymagane - do banku).

2. Magazyny nie komunikuja się między soba. Dane mogą być odczytywane lub zapisywane w magazynie tylko na „zawołanie" procesów. Ponadto dane w poszczególnych magazynach zazwyczaj nie są spójne. Każdy magazyn zawiera inny rodzaj danych ${ }^{30}$. (Przykładowo, w magazynie zawierającym numery telefonów ciag cyfr 654432342 to konkretny numer telefonu, w magazynie zamówień może to być numer zamówienia. Nie da się zatem połączyć tych dwóch magazynów).

3. Terminatory nie moga komunikować się z magazynami. Po pierwsze, aby pobrać dane z magazynu konieczny jest proces. Po drugie, dane podawane przez terminatory są różnego typu i nie da się ich zapisać w jednym magazynie ${ }^{31}$. Można co prawda buforować dane wejściowe, na przykład gdy ilość danych podawanych przez terminator jest tak duża, że system nie może przetworzyć ich na bieżąco, wprowadza się coś w rodzaju „magazynu tymczasowego”.

${ }^{28}$ E. Yourdon: Współczesna analiza..., op. cit., s. 140.

29 J. Jakieła: Materiały..., op. cit.

30 Ibidem.

31 J. Jakieła: Materiały..., op. cit. 
4. Brak czarnych dziur lub też „studni bez dna”, czyli procesów, które pobierają dane od przepływów, nie generując nic na wyjściu ${ }^{32}$. Jeżeli taki proces znajduje się w naszym systemie, możemy być pewni, że coś zrobiliśmy źle. Studnią bez dna mógłby być leniwy pracownik, który otrzymuje kolejne zadania, ale ich nie realizuje. Proceder taki bardzo szybko wychodzi jednak na jaw. Jeżeli z analizy i projektu systemu wynika, że w jakimś miejscu istnieje „czarna dziura", warto się zastanowić, czy proces ten nie jest tak naprawdę magazynem zbierającym dane.

5. Brak procesów bez wejścia, „magicznych procesów”. Są to procesy, które generują dane bez danych wejściowych. Proces potrzebuje porcji danych, aby mógł je przetworzyć i podać wynik na wyjściu. Przykładem takiego procesu, byłby generator liczb losowych. Jednak nawet taki generator potrzebuje pewnej porcji danych początkowych (np. z jakiego zbioru ma losować, ile liczb ma wylosować itp.).

6. Każdy element DFD powinien mieć własną, znaczącą nazwę. Przepływy nazywamy adekwatnie do danych, jakie przenosza. Terminatory nazywamy rzeczownikiem w mianowniku (kto lub co komunikuje się z systemem). Nazwy dla procesów to czasownik w formie czynnej oraz dopełnienie. Nazwa ma odzwierciedlać funkcję procesu. Przykładowo, jeżeli nasz proces będzie weryfikował numery telefonów klientów, można nadać mu nazwę SPRAWDŹ NUMER TELEFONU. Należy unikać nazw odnoszących się do konkretnych osób lub stanowisk w systemie. Nazwy powinny być w miarę możliwości uniwersalne ${ }^{33}$.

7. Każdy proces powinien być ponumerowany. Jest to bardzo istotne zwłaszcza w przypadku wielopoziomowych DFD, w których to proces danego poziomu może składać się z kilku procesów niższego poziomu. Numeracja procesów nie jest jednoznaczna z kolejnością ich wykonywania. DFD to system komunikujacych się asynchronicznie procesów, a nadane numery pełnią funkcję porządkową. Gdy tworzymy diagram wielopoziomowy, numeracja będzie pomagać w zorientowaniu się, z jakiego procesu pochodzą procesy niższego szczebla ${ }^{34}$.

8. Należy unikać nadmiernie złożonych DFD. Nie wszystkie systemy da się opisać w prosty sposób. Dzięki zastosowaniu wielopoziomowości możemy opisywać bardzo skomplikowane systemy korzystając z diagramów, które mieszczą się na kartce formatu A4 i zawierają nie więcej niż sześć procesów oraz koniecznych przepływów, terminatorów i magazynów. DFD ma być przejrzysty i zrozumiały dla laika. Należy unikać zbyt skomplikowanych diagramów,

${ }^{32}$ „Unikaj nieskończonych studni, czyli procesów mających same wejścia bez żadnych wyjść. Wśród analityków znane są także jako „czarne dziury” przez analogie do gwiazd, których pole grawitacyjne jest tak silne, że nawet światło nie może go opuścić". E. Yourdon: Współczesna analiza..., op. cit., s. 148.

${ }^{33}$ Ibidem, s. 142-143.

34 „Jedyną rzecza, o której musisz pamiętać, jest to, że niektórzy użytkownicy uznaja, że schemat numeracji implikuje kolejność wykonania. Znaczy to, że gdy takiemu użytkownikowi pokażesz DFD, może zapytać „Czy to znaczy, że proces 1 jest wykonywany najpierw, następnie proces 2, a potem 3?”... Jest zupełnie inaczej. Model DFD to sieć komunikujących się asynchronicznych procesów, co jest w istocie właściwą reprezentacją sposobu, w jaki działa większość systemów. Pewna kolejność może być implikowana obecnością lub brakiem danych (np. może okazać się, że proces 2 nie może wykonać swojej funkcji, dopóki nie otrzyma danych od procesu 1), ale schemat numerowania nie ma z tym nic wspólnego." E. Yourdon: Współczesna analiza..., op. cit., s. 142. 
a jeżeli już taki powstanie, należy zastanowić się, czy można go uprościć lub czy system nie potrzebuje przebudowy ${ }^{35}$.

Diagram przedstawiający cały system nosi nazwę diagramu kontekstowego. Składa się on tylko z jednego procesu oraz zewnętrznych terminatorów i magazynów. Proces ten reprezentuje cały projektowany system. Taki diagram ma dostarczyć jedynie informacji o tym z kim nasz system się komunikuje ${ }^{36}$.

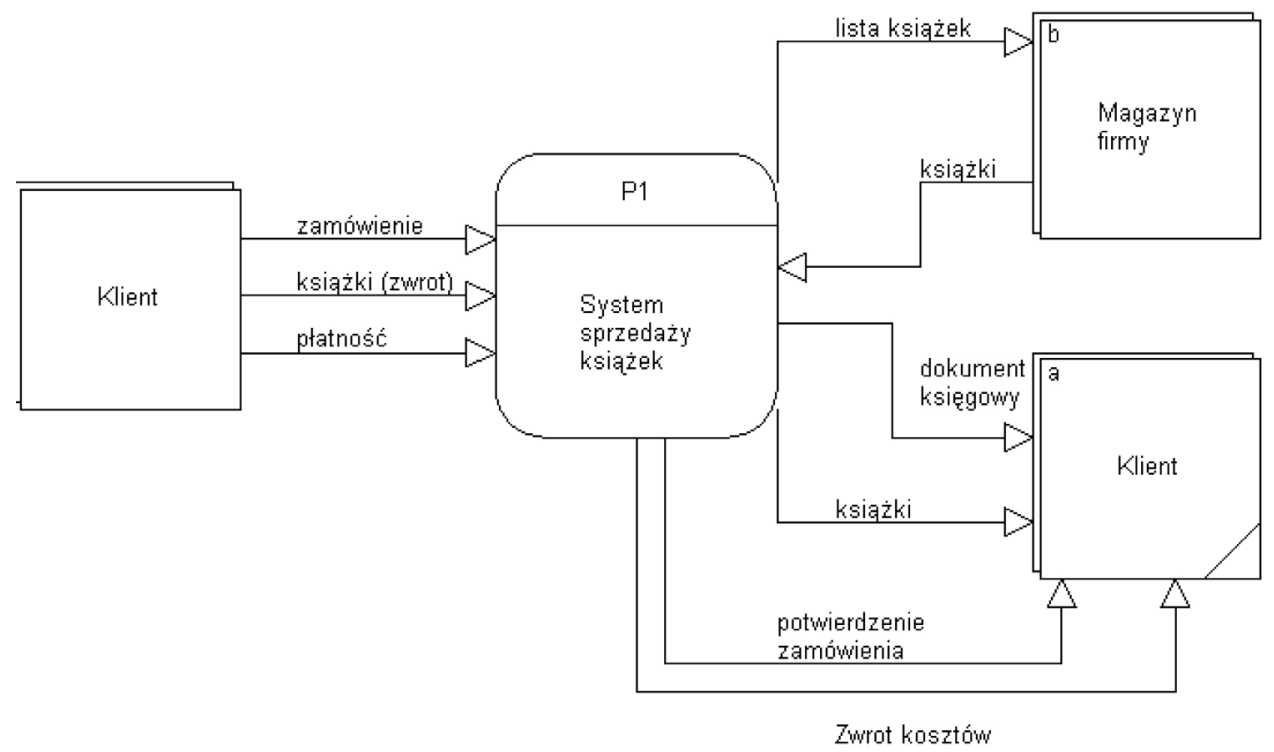

Rys. 2. Przykład diagramu kontekstowego.

Rysunek pochodzi ze strony internetowej: http://jjakiela.prz.rzeszow.pl/dfd.htm

Bezpośrednio po diagramie kontekstowym umieszcza się właściwy już DFD pierwszego poziomu. Diagram ten może się składać z kilku procesów i wielu magazynów, terminatorów i przepływów. Diagram ten nazywa się Diagramem 0. Każdy z procesów może zostać rozbity na mniejsze części, które zostana umieszczone na diagramie niższego poziomu. Taki diagram będzie brał nazwę i numer od procesu jaki opisuje. Diagram 1 to zatem diagram opisujący, czy też rozbijający na mniejsze procesy, proces 1 z Diagramu 0. Analogicznie Diagram 3 opisuje proces 3 z Diagramu 0 a Diagram 2.2 opisuje proces 2.2 z Diagramu $2^{37}$.

35 „Nie buduj DFD ze zbyt wieloma procesami, przepływami, magazynami i terminatorami. Na ogół oznacza to, że na pojedynczym diagramie nie powinno wystapić więcej niż sześć procesów oraz powiązanych z nimi magazynów, przepływów i terminatorów. Inaczej mówiąc, DFD powinien swobodnie mieścić się na standardowym arkuszu papieru formatu A4". Ibidem, s. 145.

36 „DFD najwyższego poziomu składa się tylko z jednego procesu, reprezentującego cały system; przepływy danych pokazują interfejsy między systemem i terminatorami zewnętrznymi (wraz z ewentualnymi magazynami zewnętrznymi). Ten specjalny DFD nazywa się diagramem kontekstowym". Ibidem, s. 150.

37 „DFD bezpośrednio poniżej diagramu kontekstowego nazywa się Diagramem 0. Przedstawia najwyższy poziom widzenia głównych funkcji systemu oraz głównych interfejsów między tymi funkcjami”. Ibidem, s. 150. 
Dobry diagram powinien mieć tyle poziomów, ile potrzeba do wyjaśnienia działania systemu, nie wszystkie gałęzie systemu muszą być jednakowo rozbudowane.

Analogiczna sytuacja ma miejsce w przypadku magazynów. Jeżeli z magazynem komunikuje się proces A i pobiera z niego dane, to na diagramie niższego poziomu tego procesu też będą pobierane dane z magazynu. Co więcej, na diagramie niższego poziomu dane moga być tylko pobierane. Żaden z podprocesów procesu A nie może wykonać akcji zapisywania danych do magazynu.

Konstruowanie diagramu należy rozpoczynać od diagnozy systemu, jaki będziemy projektować i identyfikacji zachodzących w nim zdarzeń. Przede wszystkim należy zidentyfikować obiekty zewnętrzne, z którymi komunikować się będzie system, i dopiero po ich zidentyfikowaniu przystapić do rozrysowania wstępnego diagramu, który następnie rozbudowuje się w górę i w dół ${ }^{38}$.

\section{Diagram przepływu danych w placówce informacyjnej Call Center}

Call center to specyficzna placówka informacyjna prowadząca kontakty z klientami przy pomocy telefonu. Tworzenie diagramów przepływu danych należy zacząc od zdefiniowania zachodzących w systemie zdarzeń i określenia terminatorów, niestety, podręczniki nie podaja informacji na temat szczegółowych zjawisk zachodzących w call center. Więcej informacji możemy uzyskać od osób pracujących w takich placówkach, które mają doświadczenie potrzebne do zdefiniowania schematów w działaniu call center.

Innym wyjściem byłoby zapoznanie się ze specyfikacją opracowaną na potrzeby już istniejącego call center, niestety są to bardzo ściśle strzeżone tajemnice handlowe i firmy nie chcą się nimi dzielić. Jeżeli oczywiście w ogóle posiadają taki projekt, gdyż wiele mniejszych firm, zatrudniających w dziale call center 4-5 osób, nie ma żadnego systemu, poza telefonem i człowiekiem go obsługującym. Duże przedsiębiorstwa, takie jak telewizja cyfrowa Canal $+{ }^{39}$, posiadaja bardzo dobrze zorganizowane i opracowane systemy autorskie (zintegrowane z placówkami zagranicznymi), ale ich specyfikacje podlegają tajemnicy handlowej. Bazowanie na dokumentacji rozwiązań komercyjnych lub open sourcowych (Shugar $\mathrm{CMS}^{40}$, Microsoft Dynamice ${ }^{41}$ ) też nie da szukanej odpowiedzi, specyfikacje te dotyczą bowiem konkretnego systemu i jego działania.

38 „Łatwo sobie wyobrazić rozpoczęcie od diagramu kontekstowego, następnie sporządzenie Diagramu 0 i stopniowe schodzenie do niższych poziomów szczegółowości (...) z podejściem tym są związane pewne problemy; lepiej jest najpierw zidentyfikować zdarzenia zewnętrzne, na które system powinien odpowiadać i użyć ich do zbudowania pierwszego, wstępnego DFD. (...), że wstępny DFD może być rozwijany zarówno w górę (przez tworzenie DFD wyższego poziomu), jak i w dół (tworzeniem DFD niższego poziomu). Narazie wystarczy zapamiętać, że organizacja i prezentacja zrównoważonego zbioru DFD niekoniecznie musi odpowiadać strategii budowania tych poziomów". Ibidem, s. 156.

${ }^{39}$ CANAL+ Cyfrowy. [online]. [dostęp: 25.10.2012]. Dostępny w World Wide Web: <http:// www.canalpluscyfrowy.pl/pl/kontakt>.

${ }^{40}$ SUGAR CRM. [online]. [dostęp: 25.10.2012]. Dostępny w World Wide Web: <http://www. sugarcrm.com/crm/>

${ }^{41}$ Microsoft dla Małych i Średnich Firm. [online]. [dostęp: 25.10.2012]. Dostępny w World Wide Web: <http://www.microsoft.com/business/smb/pl-PL/dynamics/crm-4.mspx>. 
Z pomoca przychodzi Internet, gdzie można dotrzeć do wielu artykułów zwiazanych tematycznie z call center. W części z nich autorzy umieszczaja krótkie opisy, diagramy obrazujące funkcjonowanie systemu takiej placówki.

Paul Kirvan, amerykański analityk, w artykule pod tytułem Lista kontrolna planu awarii call center ${ }^{42}$ umieścił prosty diagram oraz następujący opis call center. „Relevant information the agent needs for the call is displayed on their system. The agent can interact directly with the company's information systems and databases while still on the call. Call center system elements are typically linked by a local area network, such as 10/100 MB Ethernet or Gigabit Ethernet, depending on the number of agents, number of calls and the amount of data to be moved"43.

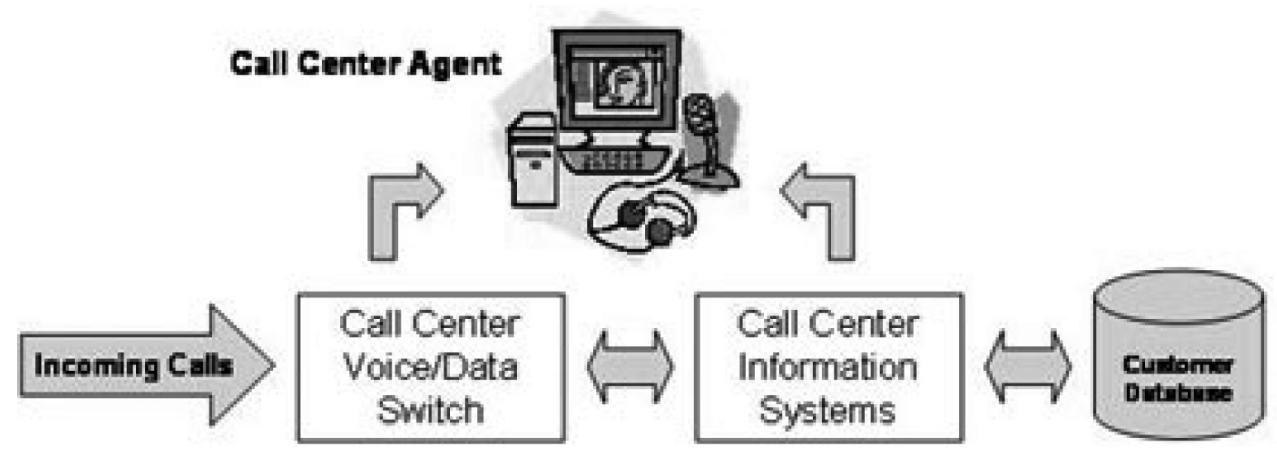

Rys. 3. Typowe call center

Ten krótki opis daje wiele cennych informacji o działalności call center. Dowiadujemy się z niego o istnieniu agenta, który jest konsultantem obsługującym rozmowy telefoniczne. Dowiadujemy się również o istnieniu systemu informatycznego i bazy danych oraz, że ich obsługa odbywać się może na bieżąco w trakcie prowadzenia rozmowy. Elementy te sa połączone szybka siecią lokalna, co oznacza krótki czas przesyłania danych. Dzięki temu każdy agent pracuje na tym samym, na bieżąco aktualizowanym zestawie danych. Przyglądając się schematowi call center, można zauważyć jeszcze jeden ważny element - Call Center Voice/Data Switch. Paul Krivan nie wyjaśnia, czym jest ten element systemu, ale analizując schemat można się domyślić, że jest to automat przekierowujący rozmowy do konsultanta i pobierający jakieś dane $z$ systemu informacyjnego. Jest to moduł Automatic Call Distribution (ACD) służący do automatycznego rozdzielania rozmów pomiędzy agentów oraz, w bardziej rozbudowanych systemach, automatycznego identyfikowania rozmówcy.

${ }^{42}$ SearchDisarterRecovery. Call center disaster recovery plan checklists. [online]. [dostęp: 25.10.2012]. Dostępny w World Wide Web: <http://searchdisasterrecovery.techtarget. com/tip/Call-center-disaster-recovery-plan-checklists>.

${ }^{43}$ (ang.) - Istotne informacje potrzebne agentowi do prowadzenia rozmowy telefonicznej sa wyświetlane w systemie. Agent może wykonywać operacje w systemie informatycznym i bazach danych firmy i jednocześnie rozmawiać przez telefon. Elementy systemu call center są zazwyczaj połączone w sieciach lokalnych, takich jak 10/100 MB Ethernet lub Gigabit Ethernet, w zależności od liczby agentów, liczby połączeń i ilości danych do przeniesienia. 
Przydatne informacje o procesach jakie zachodzą w call center podaje strona www.eu.gov.hk. Nie jest to witryna powiązana $z$ unia europejska, a skrót EU w tym wypadku oznacza Efficiency Unit. Jest to specjalna jednostka w strukturach administracyjnych Hongkongu zajmująca się wdrożeniami nowych technologii i usprawnień w administracji. Jednym z takich projektów było właśnie stworzenie call center zajmującego się rozwiązywaniem problemów mieszkańców.

Z opisu dowiadujemy się kilku nowych szczegółów. Konsultanci w Hongkongu nie sa pracownikami cywilnymi, przechodzą specjalistyczne szkolenie z zakresu obsługi klienta, a większość wiedzy merytorycznej czerpią z bazy wiedzy czy też systemu informacyjnego. Jeśli baza wiedzy nie zawiera poszukiwanej informacji, dokonuje się konsultacji z odpowiednim działem, a uzyskane informacje wprowadza do bazy. Konsultant otrzymuje zapytanie od mieszkańca, sprawdza, czy odpowiedź znajduje się w bazie danych. Jeżeli nie znajdzie jej w bazie, musi skontaktować się z innym departamentem, a otrzymane informacje wpisuje do bazy danych. Ponadto $w$ trakcie rozmowy tworzy specjalny formularz dla danej osoby i wypełnia podstawowe informacje dotyczące rozmowy i mieszkańca. Z opisu systemu call center w Hongkongu dowiadujemy się również kilku rzeczy na temat systemu ACD. Nie tylko pozwala on rozprowadzać rozmowy do poszczególnych konsultantów, ale umożliwia dzwoniącemu dokonanie wyboru (w tym wypadku języka), do jakiego konsultanta bądź grupy konsultantów chce się dodzwonić. Jest to automat, który pozwala wybrać na przykład pomiędzy działami technicznym, obsługi lub tele-sprzedaży.

Trzecim przykładem, który wybrałem do analizy, jest schemat ze strony internetowej Siemens Polska. Siemens jest firmą zajmującą się produkcją sprzętu komputerowego, AGD, aparatów telefonicznych, inteligentnego oświetlenia. W celu poprawienia jakości obsługi i wsparcia technicznego swoich klientów firma ta zdecydowała się na wprowadzenie następujących narzędzi:

- Contact Center (rozdział i kierowanie telefonów oraz korespondencji elektronicznej),

- System informatyczny Call Desk (rejestracja i obsługa zgłoszeń),

- Internetowa baza danych gotowych odpowiedzi mFAQ (zbiór opracowań technicznych będących odpowiedzią na najczęściej zadawane pytania),

- Internetowa baza danych dokumentacji technicznych i informacji produktowych ${ }^{44}$.

I tutaj pojawiają się wcześniej wymienione już elementy, takie jak automat obsługujący zgłoszenia czy baza danych z dokumentacją firmową. W tym przypadku baza szybkich odpowiedzi FAQ ${ }^{45}$ oddzielona została od bazy specyfikacji technicznych produktów. Pierwsza z nich jest prawdopodobnie dostępna również dla klientów, na przykład na stronie internetowej, druga natomiast to baza wymagająca już pewnej podstawowej wiedzy o firmie i przeznaczona jest tylko dla przeszkolonych konsultantów. W odróżnieniu od dwóch poprzednich projektów tutaj call center jest elementem większego systemu, pełni rolę bufora pomiędzy klientami a wsparciem technicznym. W systemie firmy Siemens istnieje dodatkowa droga kontaktu, poprzez stronę internetowa, ale wszystkie

${ }^{44}$ SIEMENS. [online]. [dostęp: 25.10.2012]. Dostępny w World Wide Web: <http://www. automatyka.siemens.pl/solutionandproducts_ia/1254.htm>.

${ }^{45}$ Frequently Asked Questions - często zadawane pytania. 
zgłoszenia trafiają do bazy danych zgłoszeń i informacja o nich pozostaje w firmie. Call center pozostaje w kontakcie z reszta firmy i udziela informacji na podstawie rozwiązań wypracowanych przez dział techniczny (lub inny, np. finansowy) i ma dostęp do bazy danych zgłoszeń i kontaktów. Konsultanci call center nie są pracownikami decyzyjnymi i rozwiązania nieznajdujące się w procedurze muszą zostać skonsultowane z kierownictwem lub specjalistą. Dopiero wtedy takie rozwiązanie może zostać dopisane do procedur.

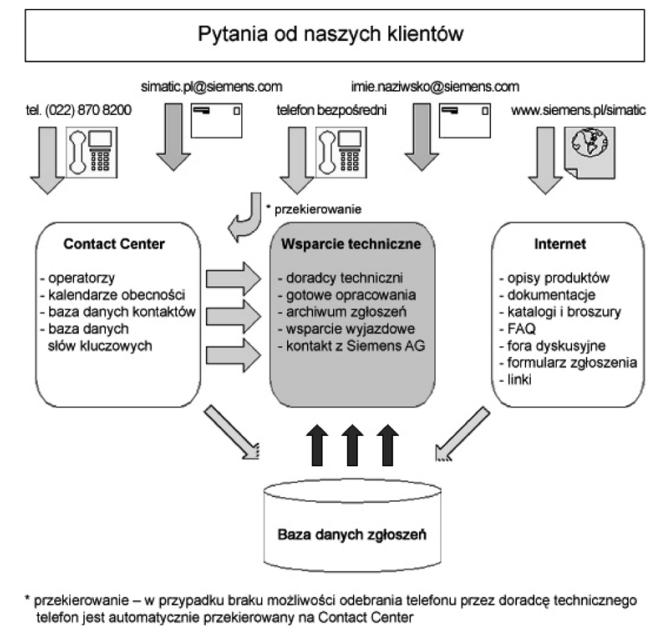

Rys. 4. Schemat call center umieszczony na stronie internetowej Siemens Polska

Ostatnim wybranym źródłem informacji na temat funkcjonowania call center jest encyklopedia internetowa ITpedia ${ }^{46}$. W odróżnieniu od Wikipedii, która zawiera wiedzę ogólną o wszystkim, projekt ten jest poświęcony tylko zagadnieniom IT i jest prowadzony przez wydawnictwo IDG Poland ${ }^{47}$. W artykule możemy znaleźć następująca informacje: „Call Center jest inteligentnym systemem wspomagania zgłaszających się abonentów i personelu (agentów firmy) obsługującego klientów, funkcjonującym dzięki współpracy telefonu z komputerem. Połączenia przychodzące są równomiernie kierowane do właściwych agentów firmy, mających natychmiastowy dostęp do informacji o klientach i produktach (usługach) firmowych, umożliwiających udzielanie szybkiej odpowiedzi bądź rozwiazanie problemu klienta".

Cztery zaprezentowane opisy pochodzą z różnych źródeł i odległych części świata. Wybór nie był do końca przypadkowy, chodziło bowiem o ukazanie części wspólnych dla każdego call center. Mimo różnic kulturowych, jakie dzielą USA, Polskę i Hongkong, okazuje się, że istnieje wspólny zbiór funkcji i elementów dla każdej z wybranych placówek. Te elementy posłużą do stworzenia listy zdarzeń oraz oznaczenia terminatorów i magazynów systemu call center. Oznaczenie tych elementów pozwoli na zbudowanie pełnego diagramu przepływu danych dla takiej instytucji.

${ }^{46}$ ITpedia. [online]. [dostęp: 25.10.2012]. Dostępny w World Wide Web: <http://itpedia. pl/index.php/Call_Center>.

${ }^{47}$ Idg.pl. [online]. [dostęp: 25.10.2012]. Dostępny w World Wide Web: <http://www.idg.pl/>. 
Mając określone podstawowe elementy call center, wspólne dla wszystkich tego typu projektów, można przystapić do określenia listy zdarzeń. Na liście zdarzeń powinny znaleźć się elementy, które w budowie diagramu wykorzystamy do określenia procesów i przepływów w systemie. Ponadto określone powinny zostać terminatory, czyli elementy zewnętrzne, z jakimi komunikuje się system, oraz magazyny, w których system przechowuje informacje. Określone w ten sposób elementy umieszczone zostaną na diagramie wstępnym, który po przemodelowaniu stanie się kompletnym, wielopoziomowym diagramem przepływu danych call center. Wspólne elementy dla wybranych przykładów call center:

- Agenci (konsultanci),

- Klient,

- Kierownik/specjalista/dysponent,

- System rozdzielania rozmów do konsultantów,

- Baza danych abonentów (skrypt informacyjny) dane klientów.

Zdarzenia, jakie zachodziły w wymienionych systemach:

- Pobranie/ zweryfikowanie danych rozmówcy,

- Przekazanie rozmowy do konsultanta,

- Konsultant odbiera telefon,

- Konsultant sprawdza informacje w bazie danych,

- Konsultant przekazuje problem do specjalisty,

- Konsultant udziela odpowiedzi klientowi,

- Konsultant zapisuje wynik rozmowy w bazie danych,

- Konsultant uaktualnia skrypt informacyjny.

Z powyższej listy widać, że większość zdarzeń zachodzących w call center jest związana z konsultantem, który wykonuje bardzo wiele czynności: odpowiada na zgłoszenia, wyszukuje odpowiedzi w skrypcie informacyjnym, przekazuje sprawy do specjalistów i dokonuje aktualizacji danych. Wstępnie można więc zastapić cała grupę tych procesów jednym, nazwanym konsultantem. Elementem zewnętrznym systemu jest klient. To z nim komunikuje się konsultant. Nie jest to jednak jedyny terminator, terminatorem jest też kierownik/specjalista. Mimo że jest pracownikiem call center, tak naprawdę jest oddzielną komórka, z którą następuje komunikacja w wybranych momentach. Skrypty informacyjne i baza danych klientów to z kolei magazyny. Dochodzi w nich do zapisywania i odczytywania danych przez konsultanta. Pozostaje zdiagnozować czym jest system przekierowywania rozmów, czy jest to kolejny zewnętrzny element, czy proces działający w systemie. Przy założeniu, że jest to proces, przykładowy diagram wstępny call center wyglądałby tak: 


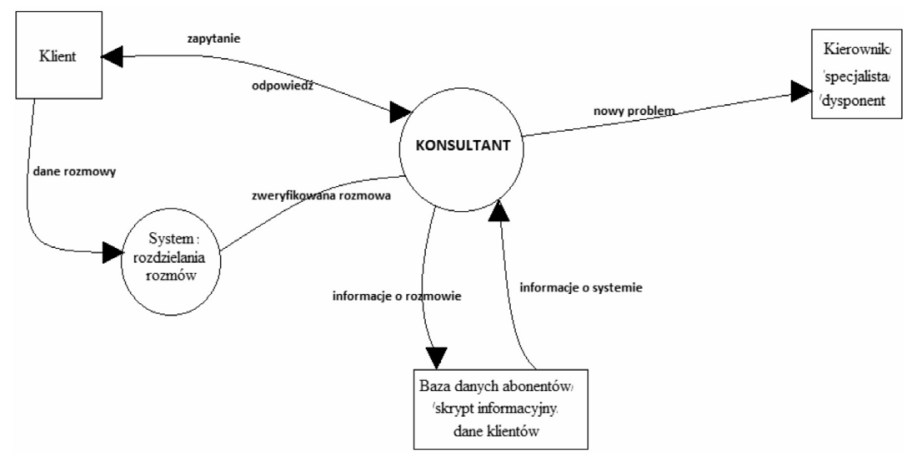

Rys. 5. Wstępny diagram przepływu danych call center

Schemat ten zawiera jednak podstawowy błąd - połączone są w nim magazyny zawierające różne rodzaje danych: klienci, rozmowy i informacje o firmie. Na tym etapie nie wiemy jeszcze, czy wszystkie magazyny znajdą się w naszym systemie. Spróbujmy określić, które z elementów znalazłyby się w diagramie najwyższego poziomu '0' i na diagramie kontekstowym. Powinny się na nich znaleźć kluczowe elementy i w wielu przypadkach taki diagram może być bardzo podobny do diagramu wstępnego. Analizując funkcje wykonywane przez konsultanta, można zauważyć dwa podstawowe ich typy. Pierwszy to działania związane z wyszukaniem i przekazaniem odpowiedzi na pytanie klienta, drugi to te zwiazane z przekazaniem sprawy do specjalisty i z aktualizowaniem bazy skryptu informacyjnego. Są to dwa równorzędne procesy, które można rozbić na kilka mniejszych. Jeżeli chodzi o bazy danych, jak na razie mamy pewność co do skryptu informacyjnego. Czy potrzebne są bazy danych klientów i rozmów? Z doświadczenia wiem, że są to połączone skrypty, dające konsultantowi informacje nie tylko o kliencie, ale i o historii jego kontaktów. Te dwie bazy połączone są więc w jeden skrypt informacji o klientach. Diagram „0" takiego systemu mógłby wyglądać jak na rys. 6 .

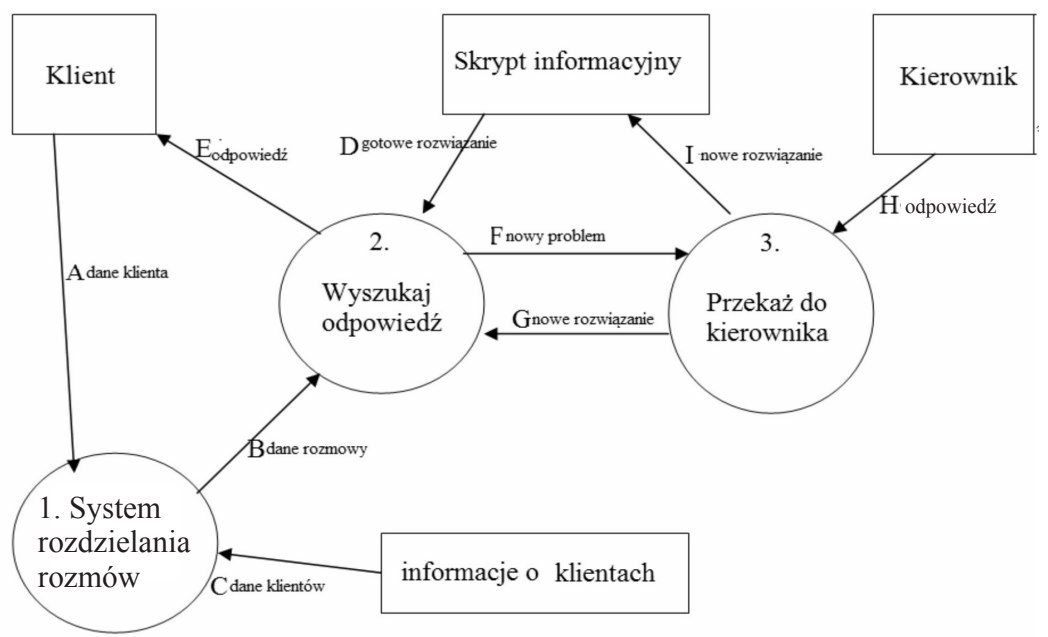

Rys. 6. Diagram przepływu danych call center - poziom „0” 
Zaprezentowany system składa się z trzech procesów, dwóch magazynów i dziewięciu przepływów. Komunikuje się on z dwoma terminatorami. System pobiera od dzwoniącego klienta dane osobowe i weryfikuje je z danymi z bazy informacji o klientach. Pobiera również informacje o ogólnym temacie rozmowy i taki zestaw informacji przesyła do konsultanta wraz z przekierowaną rozmowa. Konsultant, na podstawie uzyskanych informacji o problemie, przeszukuje skrypt informacyjny w celu odnalezienia odpowiedzi na zapytanie klienta. Jeżeli jej nie znajdzie, zgłasza nowy problem i przekazuje go do kierownictwa. Po uzyskaniu odpowiedzi kierownictwa wprowadza nowe rozwiązanie do skryptu informacyjnego i udziela odpowiedzi klientowi.

Diagram ten nie pokazuje jednak wszystkich zdarzeń, jakie zachodzą w systemie, dlatego konieczne będzie stworzenie dodatkowych poziomów diagramu przepływu danych.

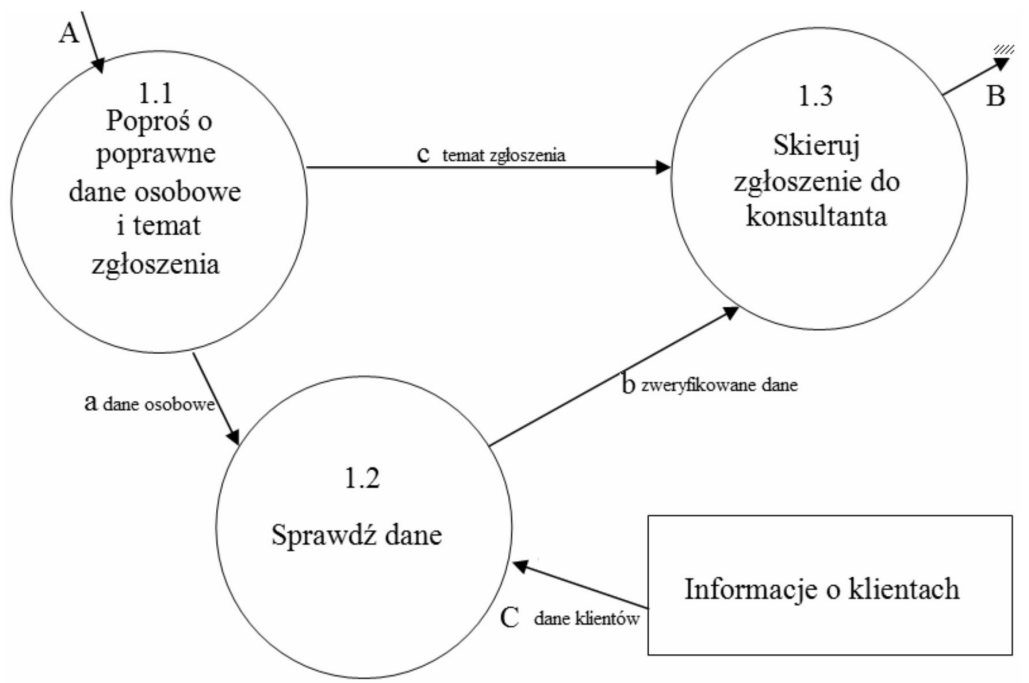

Rys. 7. Diagram 1 przepływu danych call center.

Przyjęcie zgłoszenia i przekazanie go do konsultanta.

Diagram 1, to niższy poziom diagramu dla procesu pierwszego „System rozdzielania rozmów". W wielu call centrach wprowadzono już automaty ACD, które na podstawie wprowadzanych przez rozmówcę odpowiedzi weryfikuja jego dane i temat rozmowy. Funkcja ta może być jednak funkcją pełnioną przez jakaś osobę, która będzie przekazywała rozmowy dalej. W pierwszym procesie widać, że potrzebne jest pobranie danych od klienta. Sa to dane dwojakiego rodzaju. Pierwsze to temat zgłoszenia, co decyduje o przydzieleniu rozmowy do konkretnego działu lub agenta. Drugie dane to dane osobowe. Jeżeli dzwoni do nas klient firmy, to może to być numer abonencki, na podstawie którego można zidentyfikować jego kontrakt w bazie informacji o klientach. Taki kontrakt ukazuje się konsultantowi, który prowadzi rozmowę i wie, z kim rozmawia oraz zna podstawowy temat rozmowy. Oczywiście w przypadku, gdy dzwoniąca osoba nie jest klientem firmy, nie ma ona żadnych danych w bazie i wtedy takie dane się nie wyświetlą. 
Kolejny diagram, diagram 2, to rozpisany na niższym poziomie proces „Wyszukaj odpowiedź”, bardziej złożony od procesu przekierowującego rozmowy. Wystarczy zwrócić uwagę na liczbę podprocesów, jakie znajdują się na diagramie. Jest tu ich aż pięć, wszystkie maja jednak równorzędne role. Od systemu przekierowywania konsultant otrzymuje rozmowę i dane dotyczące klienta. Pierwszym jego zadaniem jest uszczegółowienie zgłoszenia i niejako „przełożenie” zgłoszonego problemu na fachowy język. Dzięki temu będzie w stanie przeszukać skrypt informacyjny i odnaleźć gotowe rozwiązanie. Jeżeli takie istnieje, musi dokonać ponownego „tłumaczenia”, z języka specjalistycznego na taki, który zrozumie nasz klient. Formułuje więc odpowiedź na podstawie danych odszukanych w skrypcie informacyjnym. Jeśli gotowe rozwiązanie nie istnieje, wtedy na podstawie doświadczenia i informacji otrzymanych od klienta konsultant musi opisać problem i przekazać go do specjalisty. Po otrzymaniu odpowiedzi pozostaje jedynie przekazanie rozwiązania klientowi, po przełożeniu go na zrozumiały dla niego język, oraz uaktualnienie skryptu informacyjnego i wpisanie nowego rozwiazania.

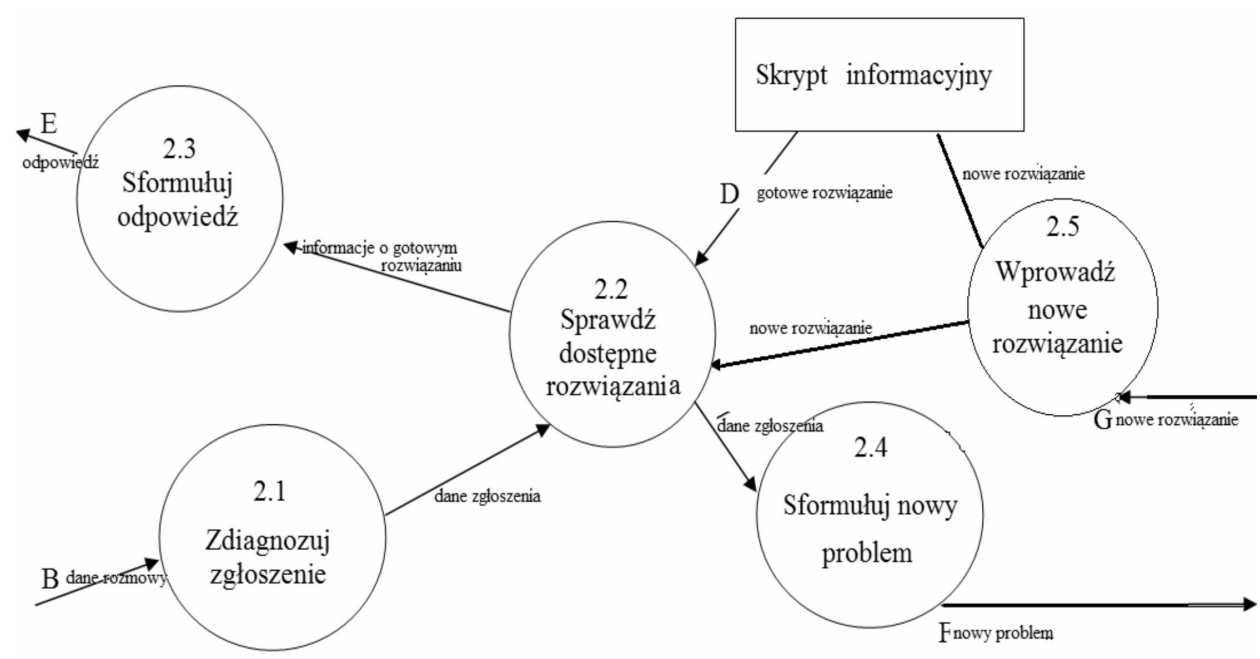

Rys. 8. Diagram 2 przepływu danych call center. Wyszukanie i sformułowanie odpowiedzi.

Pozostaje do omówienia diagram 3, który ukazuje szczegóły procesu 'Przekaż do kierownika'. Jest to w całym diagramie najmniej skomplikowane zdarzenie. Po sformułowaniu nowego problemu konsultantowi pozostaje przekazać zebrane informacje kierownikowi. Musi to zrobić w odpowiednio sformalizowany sposób, na przykład wypełniając specjalny formularz. Zwykle jednak, dla oszczędności czasu, rozwiązuje się takie problemy z najbliższym liderem w formie ustnej, tak aby klient po krótkim oczekiwaniu otrzymał odpowiedź. Kierownik lub specjalista po otrzymaniu zgłoszenia na podobnym formularzu lub ustnie może udzielić konsultantowi odpowiedzi i zaproponować rozwiązanie problemu. Do konsultanta będzie należało przełożenie takiej propozycji na język nieformalny, zrozumiały dla klienta i wprowadzenie do skryptu informacyjnego. 


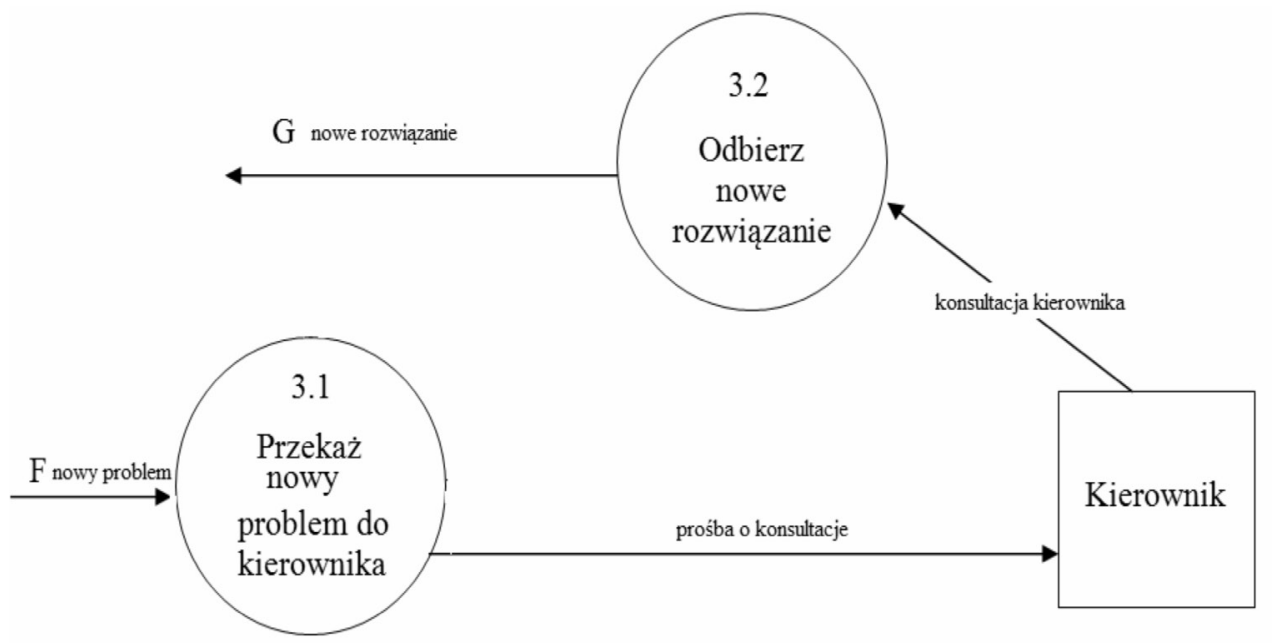

Rys. 9. Diagram 3 przepływu danych call center. Przekaż do kierownika.

Tak oto informacja przeszła przez cały system i od zapytania klienta, poprzez konsultanta i kierownika powraca $\mathrm{w}$ formie rozwiązania problemu. Zaprezentowany diagram call center to model działania takiej placówki informacyjnej. W podobny sposób można próbować opisać inne systemy informacyjne, w tym biblioteki. Do opisania pozostał jeszcze jeden element - diagram kontekstowy.

W odróżnieniu od diagramu ' 0 ' składa on się tylko z jednego procesu i elementów kluczowych systemu. Jest to, w przeciwieństwie do diagramów kolejnych poziomów, uogólnienie diagramu '0' i przedstawienie go w prostszej i jeszcze bardziej schematycznej postaci. W przypadku call center będzie to jeden proces, którego nazwy pochodzić będą od funkcji całego systemu. Może to być nazwa stanowiska konsultanta bądź agenta, może to być nazwa całej placówki. Bezpieczniej będzie użyć właśnie tej drugiej nazwy, będzie ona wskazywała, z jakim systemem mamy do czynienia. Poza procesem na diagramie kontekstowym znajdą się też magazyny i terminatory, spełniające jeden warunek: muszą być wykorzystywane w każdym „obiegu” danych w diagramie. Dlatego terminator "Kierownik" nie znajdzie się na nim, bo nie jest to element systemu wykorzystywany przy każdym przepływie. Takim elementem jest „Klient” i obydwa magazyny. W ten sposób powstał pełen diagram przepływu danych placówki informacyjnej call center. 


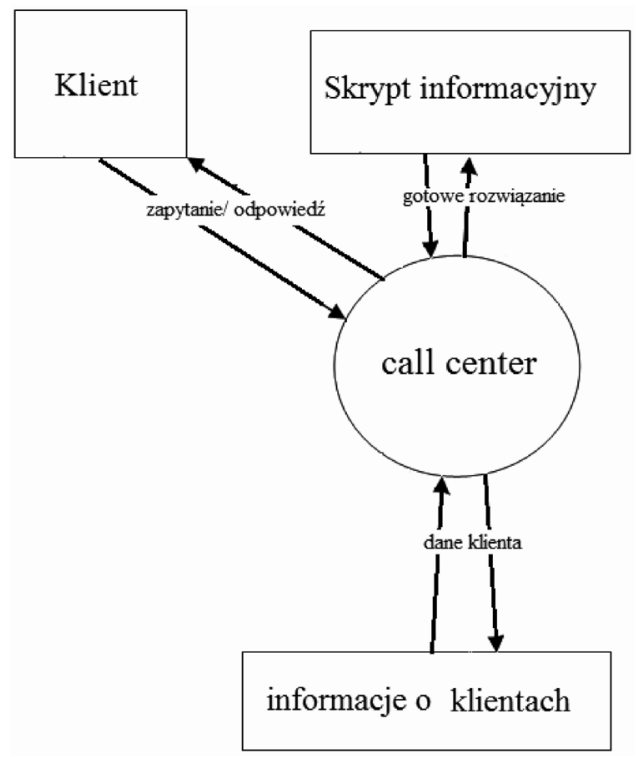

Rys. 10. Diagram kontekstowy call center.

Informacja stała się w dzisiejszych czasach towarem na wage złota. Firmy wszelkiego typu wydaja ogromne sumy na zarządzanie systemami informacyjnymi. Unia Europejska jest bardzo aktywna na tym polu, stara się aby wszyscy obywatele i firmy mogły bez ograniczeń korzystać ze zdobyczy społeczeństwa informacyjnego. Jednym z takich działań było obniżenie cen za połączenia komórkowe pomiędzy państwami UE w 2006 r. Kolejnym krokiem ma być zapewnienie dostępu do Internetu na podobnym poziomie we wszystkich państwach unijnych. Muzea, biblioteki, instytucje samorządowe i prywatne inwestuja ogromne pieniądze w udostępnianie swoich zasobów w sieci. Wszystko to zapoczątkował wynalazek Aleksandra Grahama Bell'a, który umożliwił ludziom natychmiastowa komunikację na odległość.

Call center jest instytucja, która ewoluowała wraz z rozwojem wynalazku telefonu i rozwojem społeczeństwa informacyjnego. Celem jest umożliwienie szybkiej i masowej komunikacji pomiędzy jednostką, pojedynczym klientem a firmą. Dzięki wykorzystaniu odpowiednich narzędzi zbierane są dane z każdej przeprowadzonej rozmowy, a z ich wyników tworzy się tezaurusy najczęstszych problemów, dzięki czemu wymiana informacji przebiega jeszcze szybciej i sprawniej.

\section{Bibliografia}

1. Customer Relationship Management (CRM) Information System. B. Jacobfeuerborn, M.Muraszkiewicz. W: Informacja w sieci. Pod red. B. Sosińskiej-Kalaty, E. Chuchro, W. Daszewskiego. Warszawa 2007.

2. DeMarco T.: Structured analysis and system specification. Englewood 1979.

3. Gane Ch., Sarson T.: Structured systems analysis: Tools and techniques. Englewood1979.

4. Kompendium Wiedzy o Logistyce. Pod red. E. Gołembskiej. Warszawa 2007.

5. Kopaliński W.: Słownik wyrazów obcych i zwrotów obcojęzycznych. Warszawa 1989. 
6. Kostecki M. J.: Glosariusz terminologii call center/help desk. Warszawa 2007.

7. Lotko A.: Efektywne inwestowanie w centrum kontaktu z klientem. Radom 2005.

8. Słownik Języka Polskiego. Pod red. M. Szymczaka. Warszawa 1993.

9. Słownik terminologii medialnej. Pod red. W. Pisarka. Kraków 2006.

10. Yourdon E.: Współczesna analiza strukturalna. Warszawa 1996.

11. Yourdon E.: Marsz ku klęsce: poradnik dla projektanta systemów. Warszawa 1999.

\section{Źródła internetowe}

1. Berlinger G.: Knowledge Management - Emerging Perspectives. [online]. [dostęp: 25.10.2012]. Dostępny w World Wide Web: <http://www.systems-thinking.org/kmgmt/ kmgmt.htm>.

2. Jakieła J.: Materiały do laboratoriów z przedmiotu „Informatyczne Systemy Zarządzania”. [online]. [dostęp: 25.10.2012]. Dostępny w World Wide Web: <http://jjakiela.prz.edu.pl/ labs.htm>.

3. Kubiak J.: Od Informacji do Mądrości. [online]. [dostęp: 25.10.2012]. Dostępny w World Wide Web: <http://neur.am.put.poznan.pl/mt/lnfo.pdf>.

4. Przybyłowicz P.: Wstęp do teorii Informacji i kodowania [online]. Dostępny w World Wide Web: <http://www.cmmsigma.eu/download/mat_info/wstep_do_teorii_informacji.pdf>.

\section{Summary}

The article consists of three parts, introducing data flow diagrams, and call center as an information unit. The author explains the idea and language of such diagrams (terms - like Stores, Processes, Flows, Customers, and grammar as a set of rules concerning diagram's construction). The effect is a complete data flow diagram of a call center. 